weights approximating to $35,000 \times 1,2,4$ or 8 . Many of these under conditions of varying $p \mathrm{H}$ can break up reversibly into segments which are simple submultiples of the original molecular weight. It is also interesting to notice that Bergmann and Niemann (since the above prediction) state that the chemical analysis of egg albumin enables them to deduce that this molecule consists of exactly 288 residues $(J$. Biol. Chem., 118, 301 ; 1937).

A series of models based on the truncated tetrahedron formed from the cyclol fabric and simple polymers of this, thus accounts satisfactorily for the type of molecular weight series found in some 'globular' proteins, namely, simple multiples of a basic unit of 35,000 .

\section{The Problem of Leisure}

$\mathrm{W}^{\mathrm{n}}$ have not infrequently insisted upon the problem of leisure as one of growing importance, and have emphasized the inevitable effects of the application of science to industrial processeseffects which have been put under the heading of 'technological unemployment'. As the machine lessens the volume of toil required from men and women, our social organization must be adapted to give the new services which will be demanded of it. Already the move towards a reduction in working hours is apparent and must bring with it a corresponding increase in the hours of leisure. How will that leisure be used?

The widespread interest in the possible answers to that question was shown on November 18 when more than two hundred bodies were represented at a conference arranged by the National Institute of Industrial Psychology and the British Institute of Adult Education. The problem of leisure was the problem which attracted that very large audience, and it was finally decided to set up a committee representative of bodies willing to co-operate in the carrying out of what might be called our first survey of leisure. It will consist in the first place of an investigation of the opportunities for leisure, for, clearly, any such survey will fail in its purpose if it neglect factors such as housing conditions, transport facilities, the extent to which poverty debars from participation in recreation, and other similar considerations.

The purpose of any report which may be drawn up as a result of the investigation will not be to interfere with or supplant the work of bodies already engaged in work affecting leisure activities, but to assist them.

The survey will be on broad lines and will recognize that, while many leisure pursuits require organization, resentment would arise from anything suggestive of coercion, patronage or intrusion on individual privacy.

The present suggestion is that the investigators should base their report upon a first-hand examination of the facts in certain districts which would be selected so far as possible as being typical of prevalent conditions. The following list of districts has been compiled as one where investigations would doubtless be most profitable: a town of varied districts where the factories, dwellings and recreational facilities are within easy reach of one another ; a district where the workers' dwellings and their recreational facilities are distant from their work ; a developing district where the conditions of work and leisure have been planned, but where the population has grown up without local civic conditions; a developing, but unplanned, district; a district where varied industries are scattered amid rural surroundings; and a popular holiday resort, with special reference to the increasing extension of the holiday season beyond the summer months. The increase of holidays with pay, the raising of the age of entry, and the lowering of the age of exit, from industry and the incidence of shift work are all factors which must be taken into consideration as the investigation proceeds. Duplication of effort will be avoided and investigators will be asked to distinguish carefully between the collection of fact, the collection of opinion and their own conclusions.

\section{Science News a Century Ago}

\section{Anniversary Meeting of the Royal Society}

AT the anniversary meeting of the Royal Society on November 30, 1837, the president, H.R.H. the Duke of Sussex, being prevented from attending by illness, his address was read by Francis Baily. In the report of the Council for the year, it was said: "The principal business of public interest which has occupied the attention of the Council relates to the extension of accurate magnetical and meteorological observations in different parts of the world.

"A communication having been made by Lieut. William Denison, of the Royal Engineers, of a proposal from General Mulcaster, Inspector-General of Fortifications, that the officers of engineers generally should be employed, under the direction of the Royal Society, in promoting the advancement of science, by carrying on connected series of observations relating to Natural History, Meteorology, Magnetism and other branches of physical science, and suggesting an application to Government for a grant of funds necessary for effecting so desirable an object; a Committee was appointed to consider the proposed measure, and of the means to carry into effect the recommendations contained in the letter of Baron Von Humboldt addressed in April last to the President. Conformably with the report the Council fixed on the ten following places, namely, Gibraltar, Corfu, Ceylon, Hobart Town, Jamaica, Barbados, Newfoundland, Toronto, Bagdad and the Cape of Good Hope as being the most eligible for carrying on magnetic observations . . . these places being permanent stations where officers of engineers and clerks are always to be found." A grant of $£ 500$ for instruments was afterwards obtained from the Government.

\section{Award of Two Copley Medals}

THE report of the Council also referred to the award of the various medals, two Copley Medals being awarded on this occasion, one to A. C. Becquerel and the other to J.F. Daniell. The award to Becquerel was "particularly for the production of crystals of Metallic Sulphurets and of Sulphur; by the longcontinued action of electricity of very low tension. In the memoirs particularly referred to by the Council he has especially in view to explain, by the agency of electricity of very low tension, continued for an indefinite time, the occurrence of erystalised substances in mineral veins. By his work $\mathrm{Mr}$. 